\title{
Sabk-e Hendi and the Crisis of Authority in Eighteenth-Century Indo-Persian Poetics
}

Arthur Dudney

University of Cambridge

Email: add38@cam.ac.uk

\section{ABSTRACT:}

Modern debates over the merits of the so-called Indian Style (Sabk-e Hendi) in Persian literature, which was dominant from the late sixteenth to early nineteenth centuries, have been based on problematic assumptions about how literary style is tied to place. Scholars have often therefore interpreted the Persian literary criticism of the first half of the eighteenth century as a contest between Indians who praised Persian texts written in India and Iranians who asserted their privilege as native speakers to denigrate them. A more nuanced reading suggests that the debates mainly addressed stylistic temporality, namely the value of the writing styles of the "Ancients" (motaqaddemin) versus the innovative style of the "Moderns" (mota'akhkhrrin). In the thought of the Indian critic Serāj al-Din 'Ali Khān Ārzu (d. 1756), there is clear evidence of a perceived rupture in literary culture that we can call a "crisis of authority." Ārzu was concerned because Persian poetry had been judged according to "sanad" or precedent, but poets-both Indian and Iranian-were composing in a relatively new style (tāza-gu'i, literally "fresh speech") that routinely went beyond the available precedents. All poets who know Persian well, he argued, including Indians, are allowed to innovate. While there was obvious rivalry between Persian-knowing Indians and the many Central Asians and Iranians settled in India, the contemporary terms of the debate have little in common with the later nationalism-tinged framing familiar to us.

\section{KEYWORDS:}

Seraj al-Din `Ali Khān, Ārzu, Khān-e Ārzu, Sabk-e Hendi, Indo-Persian, philology, regionalism

\section{TEXT:}

"De gustibus non est disputandum" goes an old saying. "You shouldn't argue over tastes."

Discussions of the "Indian Style" (Sabk-e Hendi) in Persian poetry, have consistently been 
framed in terms of taste or rather a lack of it, obscuring the rickety conceptual framework that makes it of dubious value for historians (Hasan, 6). The label purports to describe the Persian literary style popular from the late sixteenth to the early nineteenth century. The poetry of this period has often been dismissed as overwrought formalism obsessed with wordplay at the expense of emotion and truth. Professor Ehsan Yarshater has memorably written that "the game eventually becomes so complex and demands so much mental effort that it kills the pleasure of playing" (Yarshater, 273). Both fairminded scholars and ideologues have time and again conflated these literary characteristics with decadence and cultural decline. The formulation that "complexity is decline" has a particular historical genesis, which we explore below, but such literature was clearly performing a function in the society that produced it, whether it appeals to our tastes or not. De gustibus non est disputandum. But more importantly, why "Indian"? For twentieth-century Iranian critics, the association with South Asia of features in Persian literature that they saw as undesirable was a means of purging the Iranian national literary tradition of the supposed cultural failures of the periphery. ${ }^{1}$ This framing, reflecting a modern nation-focused mindset, is anachronistic. Historical debates

\footnotetext{
${ }^{1}$ Cf Kinra 2007, 132. There is the fact, which troubled Iranian nationalists, that most of the dictionaries of the Persianate world during that period, indisputably the golden age for pre-modern Persian lexicography, were produced in India (Perry, 329, 338-9; Tavakoli-Targhi, 106-7). For a balanced recent account, see the modern editor's preface to the 2001 Tehran edition of the dictionary Bahār-e 'Ajam, which was written by a Hindu in eighteenth-century Delhi.
} 
over Persian style need to be re-examined in a way that respects the tradition's cosmopolitanism.

What came to be called the Indian style was neither invented in India nor did it strike contemporary scholars as being particularly Indian, except to the extent that poets from the whole Persianante world could at that time find generous patronage in the Indian subcontinent. ${ }^{2}$ Nonetheless, the great early twentieth-century Iranian critic Muhammad Taqi Bahār (1886-1951) claims that the style of Persian during the Mughal period was "born from the [Indian] climate" (Bahār 1972, 66), and similar sentiments are echoed by more recent critics who point to the obviousness of the influence of "Indian taste" on the poetry (e.g. Futuhi-Rudmocjani, 37-8) while seeking in vain for direct parallels between Persian style and literature in Indic languages. ${ }^{3}$ However, practitioners of the "Indian Style," wherever they might have been from and wherever they were active as poets, never referred to themselves as such. The term is no older than the early twentieth century. It was developed by Bahār in his history of Persian prose, Sabkshenāsi, and was extended into poetic stylistics. It is, however, a deeply misleading frame of

\footnotetext{
${ }^{2}$ On India as a destination for poets see Golchin-e Macni, Browne 1959, 26ff.; also Ghani, 278ff, Dale, 199ff, and passim Yarshater, 251. On Feghāni (d. 1591, active in Shiraz) as the likely progenitor of "the Safavid-Mughal style" of poetry, see Losensky. For a readable account of the development of Persian in India, see Alam.

${ }^{3}$ The History of Iranian Literature likewise notes "The Iranians did not think of Indo-Persian as part of their national literature, but felt it to be an alien element. This is because Indo-Persian literature, that was mainly influenced by native Indian culture, shows several specific characteristics as the result of prevalent conditions peculiar to India" (Marek, 711). However, no explanation is offered as to what these "several specific characteristics" might be. The Indian critic Shamsur Rahman Faruqi comes closest to offering a direct parallel between Persian and Indic poetics, arguing that the theoretical backing for the "obliqueness of expression" typical in Persian poetry of the period may come from Sanskrit influence, but he notes that this reading is speculative in the absence of specific evidence (Faruqi 2004, $31 \mathrm{ff}$.).
} 
reference, so freighted as to be irredeemable (Kinra 2007, 142 n. 20). ${ }^{4}$ However, it represents an attempt to explain an underlying phenomenon which is both textually traceable and worth understanding.

In seventeenth and eighteenth-century northern India, Persianate literary culture was experiencing something that we can call a crisis of authority. Let us define authority (in the context of poetry) as broadly and cross-culturally as possible: It is the tool to judge whether some aspect of a literary composition is a success or a failure. The tradition does not approach the question of assessing literary merit with such a catch-all term, but it is useful to combine the concept of sanad, or literary precedent, with the idea of the consensus ('ejmāc) of contemporary poets. In practice, the two terms are often used together in the critical literature. The crisis of authority in this period sprang from the maturation of a poetics that explicitly valued newness, the "tāza-gu'i" or "Fresh Speech" movement. ${ }^{5}$ Though it was not a new phenomenon, as the sixteenth-century poet Bābā Feghāni is often seen as its progenitor, it became an acute threat to the smooth operation of literary precedent by the eighteenth century because in many cases people liked poetry that contained more and more words, phrases and metaphors for which there were no

\footnotetext{
${ }^{4}$ The interested reader should consult Kinra 2007 and Faruqi 2004 on this question. Good context is also provided in Hanaway 1989. On theoretical questions concerning the enterprise of literary history see Perkins. ${ }^{5}$ See Keshavmurthy, 28 n. 2 on the alternative translation "Speaking Anew".
} 
precedents. ${ }^{6}$ Thus critics had to struggle with the relative value of precedent and consensus.

While some aspects of this multifaceted debate may indeed be best interpreted as an Indian perspective facing an Iranian perspective, considering the crisis of authority in simple ethnic terms stops well short of a satisfactory explanation. Since Persian was a cosmopolitan literary language rather than the language of a modern nation-state, it was a learned language-even for people whom we would label native speakers-and so there was considerable scope to argue over the requisite lineage and education to compose in it. Furthermore, the way in which courtly factions in pre-colonial South Asia were related to ethnic identities is far from a settled question, and terms like Irāni and Hendustāni have frequently been misleadingly conflated with modern national identities. ${ }^{7}$ In order to enter into the debate by bracketing off such questions, let us dispense with the post facto category "Indian Style" and its implications, and instead consider contemporary formulations of the cultural politics of literary innovation: early-modern literary debates were framed primarily in terms of temporality, that is, old styles versus new styles. Geographical differences are a distant secondary concern in the critical literature. They

\footnotetext{
${ }^{6}$ The eighteenth-century critic Ārzu, introduced below, himself notes Feghāni's importance in forming the contemporary poetic style (Ārzu 1989, 20).

${ }^{7}$ The key account of factional politics under the late Mughals, Parties and Politics at the Mughal Court, 1707-1740, notes the difficulties inherent in such terminology without satisfactorily resolving them (Chandra, 13-19). As Mana Kia notes, it is in part a problem of sources: Two key histories used by Chandra and by Zahiruddin Malik in his The Reign of Muhammad Shah, the other standard work on the subject, were written under East India Company patronage in the 1780s and neither scholar has accounted for this colonial context (Kia 2014, 301-2). Obviously contemporary sources like tazkiras frequently deploy ethnic or group terminology, but careful scholarship will be required to illuminate how such categories were understood by the writers.
} 
come into play because of the recognition that literary trends diffuse unevenly over vast territories such as the Persianate world.

By being conscious of the trap of anachronism we might assume that contemporary Iran interested modern Indians not because it was seen as the "mother culture" but because it was a self-evidently important part of the Persianate world. Nevertheless, it is undeniable that Iran and India slid apart culturally in the late eighteenth century, so that by the nineteenth century Indians had lost faith in their ability to write Persian (Faruqi 1998). However, projecting this loss of faith onto earlier times would be problematic because this nineteenth century moment is separated from earlier history by enormous political changes in in India and Iran, the beginning of direct colonialism, and the emergence of nationalism.

This article will use an important literary debate involving Serāj al-Din 'Ali Khān, known by his pen-name (takhallus) Ārzu, to offer some thumbnail sketches of how the crisis of authority played out. Ārzu was a fixture in the literary gatherings of Delhi from early 1720 and just before his death in Awadh in 1756. He was respected, if not quite revered, as a poet, but made a name for himself primarily as a scholar. ${ }^{8}$ Indeed, even the twentiethcentury critic Bahār, discussed above, expresses a grudging respect for Ārzu as the period's

\footnotetext{
${ }^{8}$ The twentieth-century editor of several of his works, Muhammad Akram, considers him the best critic of his time (Akram 1981, xliii). Ārzu's magnum opus was a philological work called Mosmer (Fruitful), published as Arzu 1991. He wrote several other works of criticism, dictionaries and poems. Though scholars have become interested in Ārzu, the only long analysis of his works in English, besides my PhD dissertation (Dudney 2013), is the editor's preface to Mosmer (Khatoon). For a Persian summary of Ārzū's approximately thirty known works, see Rahimpoor 2008 and in more detail Rahimpour 2012.
} 
consummate critic (Bahar 1970). ${ }^{9}$ The literary scene at this time was contentious, and research (tahqiq) was a weapon. Ārzu's feud with Shaikh Muhammad 'Ali Hazin, who in Indian cultural memory even in our time plays the role of the irascible Iranian émigré who looked down upon Indian culture, is widely known. ${ }^{10}$ This is in no small measure because Hazin's character slots him easily into the simplistic Indians-versus-Iranians narrative. That Ārzu considered Hazin obnoxious is clear from the way in which he deals with him in his tazkera Majma' al-nafā'es (A Collection of Precious Things, 1750-1/1164), claiming among other things that Hazin apparently set out to slander India and everyone there "from the beggar to the king (guyā' ellat-e gha'i-ye neweshtan-e resāla-ye mazkur mazammat-e ahl-e hend wa hend ast az gadā tā pādeshāh)" (Ārzu 2004, 379). ${ }^{11}$ Ārzu's broadside against Hazin, Tanbih al-Ghäfelin (Admonition to the Heedless, c. 1744/1157), divided Delhi's literary world. ${ }^{12}$ However, the substance of their disagreement as represented in Tanbih al-Ghäfelin was not personal animosity but differing views on style. According to Ārzu, "obviously because Hazin is so devoted to the discourse of the Ancients (qodamā), he takes nothing at all from the Moderns (mota'akhkherān)," and for Ārzu this is as an unacceptable kind of literary

\footnotetext{
${ }^{9}$ Bahār admires Ārzu's lexicon Cherāgh-e Hedāyat as the best exemplar of a new style of critical work. Recent critics who have recognised the importance of Indian criticism include Mahmud Futuhi-Rudmojani, Cyrus Shamisa (e.g. preface to Shamisa 2002) and Muhammad Reza Shafici Kadkani (Shafici Kadkani 1996, 23). See also Rashid.

${ }^{10}$ See, for example, Kirmani, 30.

${ }^{11}$ See Kia 2011, 196ff. and 2014, 298 for a good account of Ārzu's rhetoric. Kia (2012) argues convincingly that Hazin's antipathy to India needs to be seen through the lens of his personal experience, and should be understood not as indicting Indian culture so much as lamenting his inability to return to his devastated native land.

${ }^{12}$ Ārzu describes the situation in his tažkira entry on Qezelbāsh Khān Ommid (Ārzu 2004, I, 169). For an account of Tanbih al-Ghäfelin, see Dudney 2013, $196 \mathrm{ff}$.
} 
conservatism (Ārzu 1981, 101). To better understand this criticism, let us set aside Hazin and consider Ārzū's differences of opinion with a deceased poet.

The conflict between Ārzu and Abu al-Barakāt Monir of Lahore (1610-44/1019-54) clearly demonstrates that stylistic temporality was a long-running debate. Monir was one of the greatest poets of Shāh Jahān's reign, which means that more than a full generation separated him from Ārzu, but nonetheless Ārzu felt the need to criticize him at length in two works, which will be introduced below. This debate between the living and the dead was hardly the unfair contest it would seem to be because Monir had many defenders among Ārzu's contemporaries. ${ }^{13}$ Monir had been fiercely opposed to "tāza gu'i”, which he considered a hegemonic clique whose members had the temerity to prefer their own work to that of the Classical authors, the so-called "Ancients" (Monir, 6). ${ }^{14}$ Unlike Sabk-e Hendi, "tāza gu'i" (also known as "tarz-e tāza") was a contemporary label. For Monir, there was a stark divide between the Ancients (motaqaddamin), who wrote well, and the Moderns (mota'akhkharin), who, he thought, would be better off not speaking freshly and writing more like the Ancients. (The tradition generally considers the Ancients to include the poets from Rudaki in the tenth century to Hāfez in the late fourteenth century. $)^{15}$

\footnotetext{
${ }^{13}$ Notably Vārasta Māl Seyālkoti but also lesser-known poets like Hākem Lāhori (Akram 1977: 39). The debate's staying power was such that it would be rekindled in the mid-nineteenth century by Emām Bakhsh Sahbā'i in a work called Qowl-e Faysal (The Last Word). See Akram 2009 for context on Monir.

${ }^{14}$ Kārnāma has been published in an edition including Ārzū's response, Serāj-e Monir.

${ }^{15}$ Still, Ārzu refers to the poetry of Hāfez as "namak-e tāza" (fresh-flavored, lit. fresh salt), which we can probably read as a reference to tāza-gu'i (Arzu 1991, 11). Ārzū also notes the importance of Bābā Feghāni (ibid) in forming the style that would later become dominant (cf. Losensky). Some sources consider the classical
} 
A distinction between Ancients and Moderns is critical for the question of poetic authority, and it appears to frequently have been articulated at historical hinge-points around the world. It need not be seen as a marker of cultural and political decline as it has been in the Persianate context-a slight digression into European intellectual history can corroborate this since the equivalent process is seen as the crucible of modernity and of the modern European nation-states. It is a happy accident that the translation of motaqaddemin and mota'akhkherin as "Ancients" and "Moderns" lends itself to a comparison with the roughly contemporary crisis of authority in early-modern Europe. The most celebrated account in English of what became known as the Quarrel of the Ancients and the Moderns is Jonathan Swift's satire "The Battle of the Books" published in 1704. It imagines the library of St. James's Palace in London as a battlefield where books by old authors face off against books by recent authors, with a spider and a bee also entering the fray. It is a witty allegory of the contemporary debates over literary authority. ${ }^{16}$ A grossly simplified account of the intellectual history of Europe in that period would go like this: People began to question the worth of Classical texts, which no longer seemed timeless, because, for example, if Aristotle has been proven wrong through experimental science then why should Homer be held in higher regard than modern poets? There are of course significant differences between the situation in the Persianate world and in Europe, yet the parallel is

period to have ended with Jāmi (d. 1492), referring to him as "the final poet" (shācer-e khätem) (see Browne 1959, 26; cf. Pellò).

${ }^{16}$ See DeJean and Aldridge. 
worth noting because it reminds us that our expectations about literary authority and its relationship to society must be historicized..$^{17}$ Because the development of European national languages was also tied up in questions of stylistic temporality, historians have typically framed the Quarrel as the liberation of "vigorous" vernacular languages like French and German from the heavy hand of the "dead" Latin tradition. Tellingly, this is almost always studied in the context of individual national literatures coming into their own, and a much needed pan-European perspective on how Latin as a cosmopolitan cultural system interacted with vernacular languages (for example, in Françoise Waquet's groundbreaking Latin or the Empire of a Sign) has hardly been explored and would no doubt challenge this easy bifurcation.

Another important reason for not losing sight of the European case is that the nationalist modernism of the sort that animated Bahār as he wrote the history of Persian literature was heavily filtered through European thought. ${ }^{18}$ Whether the case of earlymodern Europe is actually applicable to the Persianate world is in a certain sense irrelevant

\footnotetext{
${ }_{17}$ Marshall Hodgson has argued, correctly in the present author's view, that the key to Western misunderstandings of the Islamicate world is not the gap between East and West but rather the yawning gulf between Modern and Pre-Modern intellectual practices (Hodgson, 54). Furthermore, the division of motaqaddamin and motajakhkharin goes back a long way in Persian literary history. For example, Amir Khosrow uses it in his programmatic introduction to his divān Ghurrat al-Kamāl (Kinra 2008, 347).

${ }^{18}$ See, for example, Marashi, esp. ch. 2. Take Bahār's key term "sabk", which he glosses with the English/French word "style", and through which he attempts to systematize a science of "sabkshenāsi" or "style-ology" (Bahar 1942, preface). It is clear that he sees himself as being in dialogue with European thought because he provides copious glosses from European aesthetic theory and notes that until his time Iranians have been "ignorant" (bikhabar) of sabkshenāsi (although he notes that tazkera writers had anticipated it from the beginning of the tradition), as well as proposing through the very form of the neologism "sabkshenāsi" that the discipline run along scientific principles (cf. the Persian word for linguistics, "zabān-shenāsi").
} 
because Iranian critics like Bahār themselves understood it as germane as they were shaping their (and therefore our) understanding of the tradition. Through the agency of literary modernizers like Bahār, nineteenth-century Western Romanticism colonized nonWestern views of literary truth at exactly the moment when the literary past was being repackaged for the modern nation. Following the same pattern on the South Asian side, Persian has been assumed to be "artificial" in India, while the articulation of regional languages has been taken to represent a culturally authentic literary consciousness unshackling itself from the burden of Persian. This is a widely accepted but fundamentally problematic proposition that abstracts language from the cultural systems embedded in it. The colonial logic in this is obvious as well as its unsuitability for thinking about literature as being embedded in a tradition rather than representing an individual's self-expression. ${ }^{19}$ If pre-modern poetry were based on nothing more than self-expression, much of what Persian poets spent their time doing would have made little sense, which is precisely the conclusion reached by many colonial officials. We should not make the same mistake.

For us, early-modern Persian poetry is striking because of its rich and sometimes bewildering intertextuality-poets frequently reference other poets and depend on them

\footnotetext{
${ }^{19} \mathrm{~A}$ renewed focus on emic analysis, such as this article will present below, is required when thinking through Persianate early-modernity because the tools at our disposal for understanding language in society themselves introduce various untenable presumptions. Because linguistics is a discipline that developed in the West at a time when monolingual nation-states were assumed to be the norm, sociolinguistics typically assumes a monolingual population as the baseline, with multilingualism as the phenomenon needing further explanation (Evans, 18, 27). This could not be more wrong for modern India, and is highly problematic for both historical India and Iran, where Turkish and non-standard dialects of Persian as well as other languages coexisted.
} 
for asnād (sg. sanad), which we can formally translate as "warrants." A sanad is an example of usage, that a particular poet used a particular word, phrase or metaphor in a particular meaning, and like a royal warrant, it implies a transaction of asking for and receiving approval from one's betters. ${ }^{20}$ This is central to the enterprise of Persian poetry and yet modern critics have often failed to "allow intertextuality as a legitimate literary device" (Faruqi 2004, 22). If we consider the painstakingly researched critical works that Ārzu and other poet-scholars compiled then it becomes clear that the search for sanad was the ordering principle for literary scholarship in Persian. In Ārzu's case, it raised questions about the history of language that we would recognize as his society's equivalent of our modern discipline of linguistics. These questions are explored at length in his magnum opus, Mosmer (The Fruitful), which frames its topic as 'elm-e osul-e logha (the science of the fundamentals of language) (Ārzu 1991), but similar discussions appear in brief throughout his other early critical works. For us, linguistics is an entirely separate realm of enquiry from literary criticism: it is the study of "les langues en elles-mêmes et pour elles-mêmes (languages themselves for their own sake)" (Auroux, 30). In the pre-modern Persian tradition, there was no such distinction between the study of language and the appraisal of literature. We must therefore be receptive to critical concerns that seem very different from our own and avoid imposing anachronistic judgments on the material. For example, because later critics saw a

\footnotetext{
${ }^{20}$ It is worth noting that the term's semantic range spans the secular and the religious. The Arabic root S-N-D literally means "support, stay, rest" (Bosworth, 703). Thus isnād is the chain of transmission in scholarship used to establish the authenticity of hadith. In Ottoman and Indo-Persian usage sanad also refers to an officially sealed (and therefore authenticated) document or proclamation.
} 
connection between political and cultural decline in the period, we might assume that this was based on a perception of decline on the part of early and mid-eighteenth-century critics. Obviously the contemporary politics of Iran and India were chaotic, given the fragmentation of the Mughal state, but in the present author's reading there has come to light no reference in critical works by $\bar{A} r z u$ or his contemporaries that connects any decline in the quality of poetry with social or political decline. ${ }^{21}$ It was apparently not a relevant causality for them. Consider that a similar debate about new versus old styles took place in the fifteenth century without any reference to decline. ${ }^{22}$ Thus we should focus on what appears to have truly concerned Ārzu, namely that new poetic styles presented novel issues of interpretation because one could not depend directly on sanad.

The two works that Ārzu wrote in response to Monir are Serāj-e Monir (The Lamp for Monir) and Dād-e Sokhan (A Poetic Gift, or Poetic Justice). The dating is uncertain but Dād was probably written in 1746 and Serāj was written at some point before that. ${ }^{23}$ It is worth

\footnotetext{
${ }^{21}$ The sociological turn of the genre of poems called shahrāshub is worth exploring in this context, but not here. Whether there is relationship between poetry/poetic criticism and decline has been raised by critics (e.g. Shafici Kadkani, 21ff.) but to the present author's knowledge no proper framework for beginning to answer the question has been proposed.

${ }^{22}$ See Subtelny. Indeed, the connection between political decline and intellectual failure cannot be assumed (a point raised eloquently by Rudi Mathee in the context of Isfahan, where the twilight of the Safavids was coterminous with what could be called an intellectual renaissance). Likewise, Stacy Liechti has shown in the context of Bukhara that the commonly assumed post-sixteenth-century cultural isolation and decline of Central Asia is not borne out when one examines book endowments.

${ }^{23}$ Däd-e sokhan must be the latest of the critical works, since it mentions both Seräj-e Monir and Tambih alghäfelin (Arzu 1974, 6). A manuscript at Punjab University (Lahore) has a colophon definitively stating that Dād was written in Muhammad Shāh's thirty-eighth regnal year-however, we cannot accept this since Muhammad Shāh's rule only lasted thirty years (Akram 1974, xx). Ârzū mentions in the preface that he is now an old man, which puts the composition date not earlier than the 1740s (he was born around 1690). Furthermore, Dād is mentioned in Ārzu's tażkera Majma' al-nafā'es, which is definitively dated to 1751/1164.
} 
summarizing the contents of each to demonstrate how interconnected the critical tradition is. Serāj-e Monir is a response to a treatise by Monir under the generic title Kārnāma (Commentary). In this work, Monir critiques four poets, 'Orfi, Tāleb Āmoli, Zolāli, and Zohuri, who are his elder contemporaries and some of the most respected poets of the day.$^{24}$ His criticism is sharp but he claims that he is not an enemy (khasm) of any of the four (Monir, 7). In other words, his remarks are not intended as a personal attack but as a reasoned critique. He analyzes some fifteen verses by each. In Serāj-e Monir, Ārzu takes each of those verses, quotes at least part of Monir's commentary, and comments on the commentary. Dād-e Sokhan is based on a similar principle but with an added layer: First, Muhammad Jān Qodsi, a poet laureate under Shāh Jahān, wrote a qasida. Then his contemporary Mollā Sheydā disapproved of some lines and commented on them. This commentary was counter-commented by Monir, and finally Ārzu has added his contribution to the debate in Dād-e Sokhan while citing the positions of his predecessors. ${ }^{25}$ Additionally, Dād-e Sokhan begins with three fascinating prefaces on critical theory that Ārzu himself claims are unique in the tradition. These will be analyzed in detail below. While the prefaces are self-evidently interesting from the perspective of intellectual history, the bulk of the texts is a series of often recondite discussions of individual couplets

The editor has concluded that $D \bar{a} d$ was written in $1746 / 1159$ on the basis that the regnal year " 38 " above was probably a scribal error for " 28 " (ibid xxi).

${ }^{24}$ corfi died in 1591/999, Tāleb Āmoli in 1627/1036, Zolāli in 1622/1031 or 1625/1034, and Zohuri in 1626/1035 (Akram 1977, xxi).

${ }^{25}$ Qodsi died in 1646/1056 and Shaydā in 1632/1042. 
of comparatively less interest to a modern reader. These analyses usually turn on whether a metaphor is properly used or not. Many of the entries in both Dād-e Sokhan and Serāj-e Monir are prosaic, taking the following form:

Monir's criticism: This line has no meaning.

Ārzu's response: It is meaningful, for the following reasons ...

Often, however, Monir's critiques are aesthetic achievements in themselves, demonstrating the importance of rhetorical virtuosity in criticism. Often he takes an image in the couplet and turns it on its head to mock the poet. For example, one couplet that he really dislikes has, according to him, "not a whiff of meaning and is in need of perfume (bu’i az ma'ni nadārad va shāyestah-ye tib ast)", while elsewhere he sneers that two bad couplets should be Zolāli's epitaph (Ārzu 1977, 10, 19). On a few occasions, Ārzu accepts Monir's critique of a line as being sound.

Ārzu's prefaces to Dād-e Sokhan attempt to establish the limits of literary interpretation in a way that the tradition apparently never had before: Where does poetic authority come from? The first preface deals with mistakes in poetry and suggests a method for deciding whether a non-traditional usage (tasarrof) by an otherwise qualified Persian poet (one of the ahl-e zabān) is a legitimate intervention or in fact a mistake. Ârzu himself admits that this is "very difficult" (kheyli moshkel) task. He accepts that usage shifts over time, but also that all 
users of a language inevitably makes mistakes. ${ }^{26}$ In this preface Ārzū invokes rekhta, a literary practice that would come to define the language later called Urdu, and such a reference to something outside the Persian tradition implies that this is intended as a universal formulation about poetry. A thorough discussion of Ārzū's ambition to make his literary theory universal is not possible here, but it is significant in demonstrating how flexibly Persian fit into the Indian life-world.

$\bar{A} r z u$ proposes that the solution for determining whether a mistake has been committed is an assessment based on both research (tahqiq) and consensus among respected poets. Specifically if a usage is picked up by poets "whose standing is beyond reproach and accepted by others (keh pāya-yash mā-fowq-e radd va qabul-e digarān ast)" then it becomes an accepted usage (dākhel-e tasarrof) (Ārzu 1974, 7). Although the Ancients are in dialogue with Moderns through an unbroken tradition of sanad, they are held to different standards.$^{27}$ For example, in one case where Monir complains that 'Orfi has misused a metaphor, Ārzu retorts that in fact that kind of metaphor is only used by the Moderns so judging it according to the

\footnotetext{
${ }^{26}$ This has, of course, been a critical recognition in modern linguistics, which recognizes that speech errors occur even when the underlying linguistic concept is sound in a person's mind.

${ }^{27}$ In Mosmer, Ārzū implies that Indic words which had been borrowed into Persian but used incorrectly by the Ancients were allowed to stand, but new borrowings had to follow the Indic spelling. For example, Bengal is written in Persian as "bangāla" (i.e., ending with the letter he), while people in Indic languages write and say "bangālä" (i.e., ending with alif). Ârzū objects to the fact that under Aurangzeb the imperial chancery began using the (technically correct Indic) spelling "bangālā" in Persian documents. Hāfez, of course, used the spelling "bangāla" in his famous beyt about the sugar that goes to the parrots of Bengal so this spelling had become accepted Persian. Other more recent interventions where a Persian poet has mispronounced a borrowed Indic word are rejected as unsound (e.g. Ārzu 1991, 213).
} 
style of the Ancients (tarz-e qadim) is impossible. ${ }^{28}$ Crucially, the Ancients are by definition beyond reproach-being cited over the centuries has proved their worth-but the Moderns are not. It may seem obvious that an expression becomes accepted if people accept it, but Ārzu is making a more subtle claim: just as the Ancients' works became sanad, contemporary poets are also producing works containing what will potentially become sanad. For example, a formula that appears in Tanbih al-Ghäfelin is that "the Shaikh [i.e. Hazin] is the only sanad for X" where X is a particular expression (e.g. Ârzu 1981, 124). Indeed, Ârzu implies with his careful refutations of various usages that he is fearful that an ugly expression might become sanad. The poets of today must be vigilant lest future writers treat their solecisms as sanad.

If one accepts, as Ârzu does, that consensus among living poets is part of the production of sanad, then a survey of contemporary interpretative practices is crucial for understanding how good taste is regulated. In the third preface, Ārzu divides his contemporaries into groups according to their different methods of poetic interpretation. For example, one category is that of the "arbāb-e ma'ni" (lit. "Lords of Meaning") who focus on questions of semiotics to the exclusion of other concerns. Ārzu has a particular distaste for the interpretative practices of schoolmasters (mollāyān-e maktabi ... keh dar hend nāzem khvāhand)

\footnotetext{
${ }^{28}$ Ārzu 1977, 47, cf. 53. It is also indicative of the categorical division of Ancients from Moderns that in Ārzu's massive dictionary of Persian, the first volume, Seräj al-Lughat (1734/1137), deals with words and expressions used by the Ancients while the second, much slimmer volume, Cherāgh-e Hedāyat (The Lamp of Guidance), deals with the Moderns. Cherāgh-e hedāyat is often treated as an independent work (see Naqvi, 109-18). It is very common in manuscript and so seems to have become a standard work. For example, as C. M. Naim has shown, the poet Mir Taqi "Mir" (Ārzu's nephew and a very important Urdu poet) used a vast number of expressions from it in his autobiography, Zekr-e Mir (Naim, 14).
} 
(Ārzu 1974, 10).$^{29} \mathrm{He}$ argues the correct kind of interpretation is a holistic one that does not fall into the trap of following a single interpretative style. Furthermore, he argues that poetry should ideally to be accessible to both laymen ('avāmm) and connoisseurs (khavāss), but at the same time, the usage of expert poets should never be subject to the whims of laymen who lack the training to understand literary subtleties. ${ }^{30}$ Thus being fully versed in the tradition can be the only license for innovation.

Although he never lays it out in such terms, Ārzu's over-arching project seems to have been maintaining the unity of Persian literary culture and cementing Delhi as a focal point for it. ${ }^{31}$ In the second preface, he superficially appears to deal with the Iranian versus Indian question but actually he is making a larger point about the unity of the Persianusing world. As a keen researcher he was aware, perhaps more than any of his contemporaries, of regional differences within the Persian cosmopolis. ${ }^{32}$ For example, in Mosmer, he quotes a joke that an Indian emperor asked an Iranian out of curiosity if it is true that Iranians mix up the pronunciation of ' $q \bar{a} f$ ' and 'ghayn'. The punchline is that Iranian replied, "No, that's a mistake (qalat)!" (The humor is that the Iranian, in his reply,

\footnotetext{
${ }^{29}$ On the third preface, see Keshavmurthy, 35ff. and Abdullah, 142-7.

${ }^{30}$ A similar distinction is operative in Quranic interpretation (see Zadeh, 323, 429, 451).

${ }^{31}$ His tazkera Majma ${ }^{\complement}$ al-nafẩes certainly suggests this in the context of his social circle, but this article is limited to an analysis of his critical works.

${ }^{32}$ The term "Persian cosmopolis" (Eaton and Wagoner) is in the present writer's opinion the best way to refer to the area where Persian was the language of letters and scholarship, a vast territory stretching from Turkey in the West to the Chinese frontier in the East, from Central Asia to southern India. It is modeled on Sheldon Pollock's idea of a Sanskrit Cosmopolis, the region stretching across most of South and Southeast Asia where Sanskrit was culturally dominant (Pollock). Pollock emphasizes that such a cultural space need not have any actual political unity, even if the rhetoric of universal kingship is deployed through the cosmopolitan language.
} 
mispronounced the word "ghalat," proving that Iranians confuse the two sounds.) Jokes aside, $\bar{A} r z \bar{u}$ observes a number of regional variations such as the loss of the majhūl vowels and the shift in pronunciation of the suffix '-ān' into '-ūn' (Arzu 1991, 76).

The circulation of scholars and littérateurs in the triangle of India, Central Asia and Iran during the Mughal period is well-known. ${ }^{33}$ However, the implications of this mobility at the level of usage in poetry and formal prose are not. For example, did Iranian émigré poets dilute an Indian dialect of Persian or were they compelled to accept the Persian constructions they found in India when they worked for Indian patrons? Remarkably, we do not know. The last scholar writing in English to have made a serious attempt to examine Indo-Persian as a distinct linguistic phenomenon appears to have been Henry Blochmann in 1868, before Queen Victoria had even taken the title "Empress of India". Furthermore, his conclusions are rendered suspect by his consistent equivocation about whether a usage he identifies as Indo-Persian is actually found in both Indo-Persian and Turanian, that is, Central Asian, Persian (as opposed to the usage of western Iran). ${ }^{34}$ Clearly linguistic

\footnotetext{
${ }^{33}$ For the example of the establishment of 'Abdur Rahim Khān-e Khānan, see Lefèvre. Even less well studied is the impact of Indian people and texts on the Persianate world beyond India, but scattered references in tazkeras, such as Lotf 'Ali Baig Āzar's Ätashkada (Fire Temple, 1760) which begrudgingly admits that people in Iran know the poetry of Delhiites $(1999,523)$, could be traced.

${ }^{34}$ Blochmann refers us to works on emlā') (spelling) by Mirzā Qatil and Anvar 'Ali for further information (Blochmann, 32), and these do not seem to the present writer to be much use in answering the questions posed. Ghani, in his magisterial if under-recognised study of Persian at the Mughal court, concludes that there was no significant stylistic difference at the level of official prose (Ghani 1929-30). Another attempt to sort out how Indian fits into Indo-Persian, Heinz 1973, is undermined by his uncritical acceptance of sabk-e hendi as equivalent to Persian used in India. On another level, attempts have been made to identify specific word borrowings from Indic languages into Persian (e.g. Abidi) but present author knows of no reasoned conclusions drawn on the basis of such research.
} 
variation was not a uniquely South Asian issue but shared across the whole Persian cosmopolis. This has been obscured by the tendency of nationalism to strip away all but a single dominant dialect of a single dominant language to be identified with the nationstate..$^{35}$

As Ārzu and his contemporaries well knew, Persian usage was different in different places. Thus the key to Ārzu's claim for a universal Persian literary culture is that it does not pretend that India was not different (culturally or politically) from Iran or other places where Persian was used. Rather it assumes that for poetry, the differences did not matter. The Persian cosmopolis was capacious enough to contain cultural and stylistic variations. Ārzu quotes the famous saying attributed to Fayzi that Iranians should not claim to have superior Persian because, "We [Indians] have learned your language from your most eloquent [i.e., from books by the best writers] while you have learned it from your old geezers (pirzāl-hāa)" (Ārzu 1974, 9). In other words, everyone who uses Persian had access to the same literary tradition regardless of variation in local dialects and so on. He notes that Persians used Arabic and Turkish for centuries, and changed both languages in the process, to which no one objects. Ārzu argues explicitly-for perhaps the first time in a work of literary criticism-that Indians are allowed to modify Persian usage, provided they are properly trained. He makes it clear that everyone, even a person who speaks Persian

\footnotetext{
${ }^{35}$ Blochmann himself discusses the desirability of standardizing Persian, which would require a radical simplification of the language. Using a somewhat clumsy metaphor, he writes that "whilst many are apt to look upon stripping off the leaves as a matter of regret, I would consider it as a step towards delivering the human mind from the fetters of form" (34).
} 
natively, needs proper training before he should dare to try to change poetic usage. Indeed, as Ārzu mentions, being Indian can be a natural advantage in understanding Persian literature: the distinction between majhul and ma'ruf vowels, crucial for rhyme in classical Persian, was maintained in India but lost in most of Iran (Ārzu 1991, 84; Ārzu 1981, 4 and 142-3). Ārzu's lexicographical projects and those of his contemporaries noted which usages predominated in India and which in Iran without implying that the usages more common in India were less desirable: both were part of universal Persian. ${ }^{36}$

In Ārzu's aesthetic theory, local usages are by definition ineloquent Persian, but there is a crucial distinction between truly local usages (he cites such examples from cities in Iran, namely Shirāz, Qazvin, and Gilān, as well as from Khorāsān) and universal usages that merely happen to predominate in one place or another (Ārzu 1991, 5). Ārzu's views on linguistic standards are tied up in the hierarchy of imperial power. He observes that it is a fact that (ba-tahqiq peyvast keh) the most eloquent of languages is the language

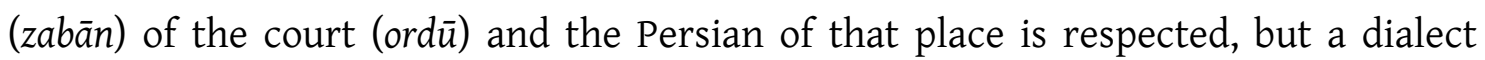
(zabān-e khāsa) of other places is not accepted in poetry or belles lettres (ensh $\bar{a})$. The poets of every place (for example, Khāqāni was from Shirvān, Nezāmi from Ganjah,

\footnotetext{
${ }^{36}$ Ārzu's dictionary Cherāgh-e hedāyat, which states its purpose as dealing with modern expressions not found in other lexicons, is meant for an Indian readership. In the text he constantly refers to which words and expressions are more common in India than in Iran. Other South Asian dictionaries from that time, such as Ānand Rām Mokhles's Mer'āt al-estelāh (discussed below), do the same thing. Because lexicography in Iran languished until the late nineteenth century, we apparently have no Iranian counterparts against which to compare these. Rajeev Kinra rightly argues that we should not assume that because dictionaries written in India, their purpose was to insert Indic words into Persian (Kinra 2011b, 367).
} 
Sanā’i from Qazvin, and Khosrow from Delhi), all composed [literally "spoke"] in the established (mogarrar) language and that was none other than the language of the court. $(\bar{A} r z u 1991,13)^{37}$

This philosophy anchors a translocal standard in the local context of any place where a poet might work. ${ }^{38}$ Indeed, the court's role as arbiter of usage survives as an orientation even when a given court no longer actually possesses any political authority because it would have widely seeded its good taste in intellectuals and writers who continue to write according to its norms even when it had faded. For a society that did not use the linguistic family trees taken for granted in modern historical linguistics, this was a powerful concept in explaining the historical development of language.

One of the many problems inherent in the label "Sabk-e Hendi" is that it implies that Persian was swamped with Indic loanwords during the Mughal period because of Indian carelessness. Although Indic words were among those that had been borrowed into Persian over the centuries, Ārzu is extremely cautious about allowing new words to be borrowed into

\footnotetext{
${ }^{37}$ Ârzu's importance in the development of Urdu literature is his extension of this principle of a universal standard of eloquence from Persian to poetry in the local Indic language that was known as rekhta and later as Urdu. His lexicon Navāder al-alfāz, a dictionary of Indic words used in the context of Persianate discourse, revises an earlier work by a certain 'Abdul Vāsec Hānsavi and takes that work's author to task for not distinguishing between the urban standard and rustic usages. Regrettably, a discussion of this is outside the scope of this article. For further information, see Dudney 2013, esp. ch 4, and Hakala, 409ff.

${ }^{38}$ For a good explanation of Ārzu's thinking on this, see Keshavmurthy.
} 
Persian. ${ }^{39}$ Indeed, he implies that the borrowing of a non-Persian word into Persian poetry is a subset of neologism or tasarrof. Since, as we have seen, neologisms are to be carefully regulated, then it is the prerogative of master poets to use Indic words just as it is their prerogative to innovate in other ways that would not be permitted for inexpert poets (e.g. Ārzu 1991, 221-2). Ārzu's friend Ānand Rām Mokhles states this principle clearly in the dictionary Mer'āt al-estelāh (The Mirror of Expressions, 1745-6/1158), which Ārzu had a hand in editing. After the entry for "maneyār" (an Indic word for kind of jeweled bangle), Mokhles writes in a "fã'eda" (a heading that we can perhaps translate as a "useful note"):

It ought to be known that some venerable persons believe that an Indic word should not be used in a Persian verse because the verse is thereby devalued. In one of the couplets written by the same master (ostād) Hakim Hāżeq [who provided the previous example] has used the word 'churi' (bangle). Likewise, Mollā Toghrā has a large number of Indic words in his verses. It means that these restrictions are for inexperienced and beginner poets. It is quite lawful for the master-poets who possess the ability to use them (Mokhles 660-1). ${ }^{40}$

Just as Ārzu and his contemporaries thought that reaching for newness for the sake of newness is not appropriate for a poet, Indic words used in Persian contrary to their correct form in the source language (because of ignorance on the part of the poet) are also an

\footnotetext{
${ }^{39}$ On the history of Persian in contact with other languages, see Fragner; on how early Persian lexicons dealt with words borrowed from other languages, see Baevskii.

${ }^{40}$ The British Library MS. Or 1813 has a lacuna here. Mokhles goes on to cite Yahyā Kāshi's use of the word "gelahri" (squirrel) in support of the same principle of mastery (this part is in the MS. On f. 252b).
} 
aesthetic fault (e.g. Ārzu 1991, 213-6.). Contrary to the assertions of some modern South Asian scholars that Ārzu was a great patriot, there does not appear to be any evidence that he was defending India per se or making a case in favor of using more Indic words in Persian poetry to better capture the Indian experience. ${ }^{41}$ He was instead defining Persian by policing the difference between permissible and impermissible innovation.

Returning to Monir in the late seventeenth century, if the central issue for him had been Iranian versus Indian usage, then we would expect him to have used the contrast between the two to carry his argument. In fact, he does not mention it in the introduction or the body of the text, and we should remember that of the four recent poets whom Monir criticizes in Kārnāma, three are Iranians. While this article has avoided social history to focus on the actual forms of literary disputation, we should not draw the false inference that because the formal debates focused on something else, Indo-Persian literary society was a utopia in which there were no perceived differences between Iranians and Indians, who always met as equals. On the contrary, in the conclusion to Kārnāma, Monir carps about the difficulties he faces in becoming a respected poet: He mentions that the four social advantages for a poet (none of which he possesses) are being old, rich, loud-voiced and

\footnotetext{
${ }^{41}$ An example of this scholarship is Zaidi, who declares that Ārzu could not bear to have people speak ill of India and so wrote out of love for his country. Ārzu famously calls out Hazin's slander of Indians, as has been described above, but this is a rhetorical brickbat in the specific context of Hazin's ingratitude towards a place that had sheltered him. We read patriotism where there need not have been any. Amir Khosrow is another figure whose willingness to assert an Indian identity and use Indic languages in literature has been interpreted as patriotism but that assumes that as in modern citizenship, he was required to choose to be Indian and not something else, but of course at that time there was no contradiction between being Indian and participating in a transnational Persianate culture.
} 
having a "connection to Iran" (nesbat-e Irān) (Monir, 25-6). Being Iranian is an automatic advantage-he claims that an Iranian can make a hundred mistakes in Persian and no one will say anything, but even if an Indian's wit is as razor-sharp as the proverbial Indian blade (tegh-e Hendi) then his work will be met with stony silence rather than praise. ${ }^{42}$ Notice, however, that Monir presumes that Iranians make mistakes in Persian poetry, anticipating Ārzu's observation, although not developing it into an axiom as the more analytic Ârzu does. The implications of Persian's dual function as a learned, cosmopolitan literary language and as a vernacular language of particular places were therefore of interest in the seventeenth and eighteenth centuries.

To conclude, it was not that a demonstrably substandard Persian poetic product was being created in Mughal India, but rather that as cultural politics changed in Iran, Iranians arrogated to themselves the right to define Persian literature universally and judge Indian Persian an aberration. Ārzu's program may be described as keeping India an integral but unique part of the Persian Cosmopolis by applying a literary standard that could account for innovation. Muzaffar Alam has argued that "attempts during the Mughal period by Indian Persian to acquire an autonomous position were feeble and exceptional", but this view needs to be nuanced (Alam 2003, 175). Indian Persian only seems "feeble" now because Ārzu lost the debate. As this article has argued, Ārzu would not have seen himself as arguing

\footnotetext{
${ }^{42}$ Kārnāma 1977: 27. Monir goes on to declare himself an Indian, but then somewhat disparages India, saying that it produced only five excellent poets, namely Mas'ud Sa'd-e Salmān, Abu’l Faraj Runi, Amir Khosrow, Hasan and Feyzi. The Indian-born poet Sheydā (mentioned above) has a similar concern (see Dudney 2013, 203).
} 
from a position of weakness against Iranians who self-evidently owned the language and literary tradition in which he was just a parvenu. Not long after Ārzu's time, the Bāzgasht-e Adabi (Literary Return) movement took hold in Iran, specifically in Isfahan. This reorientation towards older styles of Persian poetry is often interpreted as the beginning of modern Iranian cultural nationalism (though in the absence of a nation-state, it cannot of course be nationalism as we understand it). The figures associated with the movement, Seyyed Mir-'Ali Moshtāq of Isfahan (d. 1757) and his students, notably Lotf 'Ali Big Āzarar, Hātef, Sabāhi, Bidgoli, and Sahbā had no connection to India. ${ }^{43}$ Once again it was Bahār who promoted the idea of bāzgasht as a modernizing break with the past that reflected a coherent political agenda. ${ }^{44}$ It seems transnational and universal because later Iranians saw it that way, but the evidence suggests that at the time it was a local phenomenon. For it to have much significance outside its local context, one must narrow the compass of Persian

\footnotetext{
${ }^{43}$ On these poets, see Smith 2009, 200. Nor did the Bāzgasht poets themselves think much about India: It is no surprise that Āzar's Ātashkada (Fire Temple, 1760), the tazkera associated with the movement, should divide up poets by region of their birth and ghettoize Indian poets. Many poets deeply associated with India whom Ãzar included were given a non-Indian provenance due to their being born elsewhere-he mentions just seven poets from Delhi and the only one whom he quotes at length is Amir Khosrow (423-438). On the work's structure, see Matini. Dividing Indian and Iranian poets was not new, as this method had been used in tazkeras such as Nasrābādi's (1672/1083, enlarged 1681/1092), but it takes on a new significance under Āzar since the Tazkera-ye Nāsrābādi at least includes Iranian-born Mughal nobles in the India section. Ätashkada's twentiethcentury publication history appears to recapitulate the problem of Iranian neglect of India as a site of Persian literary production: Tehran-based Amir Kabir Publishers released the first three volumes of the work, edited by Hasan Saadat Nasiri, in 1957. The fourth and final volume edited by Mir Hashem Muhaddis, which contains all of the entries for the poets from India and Turan, was not released until 1999. However, as Kevin Schwartz has shown, although India was far from the minds of the Bāzgasht poets, their ideology was influential in India at a surprisingly late moment in a surprising place, Arcot (in south-eastern India) in the 1840s and 1850s (Schwartz).

44 "While there was a stylistic distinction drawn between Indian-style poetry and earlier styles, there was no accompanying social, intellectual, political, or ideological change. The Bāzgasht represented no more than a change in taste, and the 'Other' was not seen in political or social terms" (Hanaway 1993, 9; cf. Hanaway 1989). On Bahār's engagement with Bāzgasht, see Smith 2009.
} 
literature under consideration and that is precisely what later scholars did. If, as the saying goes, "Isfahan is half the world (esfahān, nesf-e jahān)", scholars have claimed Isfahan as the whole world of Persian literature for that period. Iranian nationalism meant casting off linguistic cosmopolitanism, which meant that besides contracting the Persian world to the nation-state, specifically one representative place in its territory, one also had to forget that Iran itself was-and of course still is-multilingual. ${ }^{45}$

Although eighteenth-century littérateurs like Ārzu were consciousness of regional variation in Persian, the best way to understand their critical debates is not through the over-determined and anachronistic concept of Sabk-e Hendi. Instead, as we have seen with reference to Ārzu's engagement with Hazin and Monir, a better framework considers Ancients versus Moderns. The crisis of authority in poetics led Ārzu to theorize the relationship between the tradition and contemporary poetic practices, and to address both historical usages and regional variations across the Persian Cosmopolis. He recognizes that languages are porous and fluid, while at the same time arguing for a cosmopolitan standard determined by consensus of expert poets close to power. To arrive at what Ārzu and his contemporaries were concerned with, we must peel away the interpretations of the last two centuries that have anachronistically reframed the debates on poetic authority as nationalism, cultural decline and, of course, poor taste.

\footnotetext{
${ }^{45}$ See, for example, Floor and Javadi on Azerbaijani Turkish at the Safavid court.
} 


\section{Bibliography:}

S. Abdullah, Fārsi zabān va adab, Lahore, 1977.

S. A. H. Abidi, "The Influence of Hindi on Indo-Persian Literature in the Reign of Shah Jahan (16281658)," Indo-Iranica 13.2 (1960), pp. 1-18.

W. Ahmadi, "The Institution of Persian Literature and the Genealogy of Bahâr's 'Stylistics," British Journal of Middle Eastern Studies 31.2 (2004), pp. 141-52.

S. F. Akram, ed., Sorūda-hā va nevashta-hā-ye Monir Lāhowri, Tehran, 2009.

S. M. Akram, preface to Dād-e Sokhan, Rawalpindi, 1974.

, preface to Kārnāma, Islamabad, 1977.

, preface to Tanbih al-ghäfelin, Lahore, 1981.

M. Alam, "The Culture and Politics of Persian in Pre-Colonial Hindustan," in Sheldon Pollock, ed., Literary Cultures in History: Reconstructions from South Asia, Berkeley, 2003.

M. Alam, and S. Subrahmanyam, "When Hell is Other People: A Safavid View of SeventeenthCentury Mughal India," in Judith Pfeiffer and Sholeh A. Quinn, eds., History and Historiography of Post-Mongol Central Asia and the Middle East: Studies in Honor of John E. Woods, Wiesbaden, 2006.

A. O. Aldridge, "Ancients and Moderns in the Eighteenth Century", in P. P. Wiener, ed., Dictionary of the History of Ideas, New York, 1973.

B. Anderson, Imagined Communities: Reflections on the Origin and Spread of Nationalism, London, 1983. Seraj ud-Din 'Ali Khān Ārzu, Dād-e Sokhan, ed. S. M. Akram, Rawalpindi, 1974.

-—, Serāj-e Monir, ed. S. M. Akram, Islamabad, 1977.

-_-, Tanbih al-ghäfelin, ed. S. M. Akram, Lahore, 1981.

-_-, Mosmer, ed. R. Khatoon, Karachi, 1991.

-_-, Majma' al-nafā'es, ed. Z. 'A. Khān, 3 vols., Islamabad, 2004.

S. Auroux, La naissance des métalangages en Orient et en Occident, Histoire des idées linguistiques 1 , Liège, 1989.

M. H. Āzād, Āb-e Hayāt, Lahore, 1907; tr. F. Pritchett, New Delhi, 2001.

Lutf 'Ali Baig Āzar, Ātashkadah-yi āzar, ed. Hasan Sadat Nasiri, vols. 1-3, Tehran, 1957; ed. Mir Hashem Muhaddis, vol. 4, Tehran, 1999.

S. I. Baevskii, tr. N. Killian as Early Persian Lexicography: Farhangs of the Eleventh to the Fifteenth Centuries, revised and updated by J. R. Perry, Folkestone, 2007.

M. T. Bahār, Sabkshenāsi, yā tārikh-e tatavvor-e naśr-e fārsi, Tehran, 1942.

-_-, "Sa'eb va shiva-ye u," Yaghma 23.5 (1970), pp. 244-5.

-—, Bahār va adab-e färsi: majmu'a-ye yaksad maqāla az malek al-shu'arā’ bahār, 2 vols., Tehran, 1972. Tik Chand Bahār, Bahār-e 'ajam, ed. K. Dizfuliyan, Tehran, 2001.

H. Blochmann, "Contributions to Persian Lexicography," Journal of the Royal Asiatic Society of Bengal 37 (1868), pp. 1-72.

C. E. Bosworth, "Sanad”, in EI, vol. 12, Leiden, 2011.

E. G. Browne, A Literary History of Persia: Modern Times (1500-1924), vol. 4, Cambridge, 1924 (1959 repr.).

S. Chandra, Parties and Politics at the Mughal Court, 1707-1740, $4^{\text {th }}$ ed., New Delhi, 2002. 
S. F. Dale, "A Safavid Poet in the Heart of Darkness: The Indian Poems of Ashraf Mazandarani," Iranian Studies 36.2 (2003), pp. 197-212.

J. E. DeJean, Ancients against Moderns: Culture Wars and the Making of a Fin de Siècle, Chicago, 1997.

A. D. Dudney, “A Desire for Meaning: Khān-i Ārzū's Philology and the Place of India in the Eighteenth-Century Persianate World", unpub. Ph.D. diss., Columbia University, 2013.

- - , "Urdu as Persian: Some Eighteenth-Century Evidence on Vernacular Poetry as Language Planning," in J. Hawley, A. Malhotra, and T. Williams, eds., Texts and Traditions in Early Modern North India, Delhi, forthcoming.

R. J. W. Evans, The Language of History and the History of Language, Oxford, 1998.

S. R. Faruqi, "Unprivileged Power: The Strange Case of Persian (and Urdu) in Nineteenth Century India," Annual of Urdu Studies 13 (1998), pp. 3-30.

-_- "A Stranger in the City: The Poetics of Sabk-i Hindi," Annual of Urdu Studies 19 (2004), pp. 1-93.

W. Floor and H. Javadi, "The Role of Azerbaijani Turkish in Safavid Iran,"Iranian Studies 46.4 (2013), pp. 569-581.

B. G. Fragner, Die "Persophonie": Regionalität, Identität und Sprachkontakt in der Geschichte Asiens, Berlin, 1999.

M. Futuhi-Rudmocjani, Naqd-i adabi dar Sabk-e Hendi, Tehran, 2006.

H.-G. Gadamer, Truth and Method, tr. J. Weinsheimer and D. G. Marshall, $2^{\text {nd }}$ ed., New York, 2006.

M. A. Ghani, A History of Persian Language and Literature at the Mughal Court, vol. 3, Babur to Akbar, Allahabad, 1930.

E. J. W Gibb, A History of Ottoman Poetry, 6 vols., London, 1900-1909.

A. Golchin-e Ma'ani, Kärvān-e Hend, 2 vols., Mashhad, 1990.

W. N. Hakala, "Diction and Dictionaries: Language, Literature, and Learning in Persianate South Asia", unpub. Ph.D. diss., University of Pennsylvania, 2010.

W. L. Hanaway, "Bāzgašt-e adabī," in EIr, vol. 4, 1989, pp. 58-60; online:

http://www.iranica.com/articles/bazgast-e-adabi-literary-return-a-movement-for-areturn-to-writing-poetry-in-the-korasani-and-eraqi-styles-that-b (accessed 26 January 2011).

-_-, "Is There a Canon of Persian Poetry?," Edebiyat 4 (1993), pp. 3-12.

H. Hasan, Mughal Poetry, Its Cultural and Political Value, Delhi, 1998.

W. Heinz, Der indische Stil in der persischen Literatur, Wiesbaden, 1973.

M. G. S. Hodgson, “Two Pre-Modern Muslim Historians: Pitfalls and Opportunities in Presenting them to Moderns", in J. Nef, ed., Towards World Community, New York, 1968.

P. Keshavmurthy, "The Local Universality of Poetic Pleasure: Sirājuddin 'Ali Khān Ārzu and the Speaking Subject," Indian Economic and Social History Review 50.1 (2013), pp. 27-45.

M. A. Khan, Some Important Persian Prose Writing of the Thirteenth Century A.D. in India, Aligarh, 1970.

S. K. Khatak, Shaikh Muhammad 'Ali Hazin: His Life, Times \& Works, Lahore, 1944.

R. Khatoon, editor's introduction to Mothmer, Karachi, 1991.

M. Kia, "Accounting for Difference: A Comparative Look at the Autobiographical Travel Narratives of Hazin Lāhiji and 'Abd-al-Karim Kashmiri," JPS 2.2 (2009), pp. 210-36.

-_-, "Adab as Literary Form and Social Conduct: Reading the Gulistan in Late Mughal India," in A. Korangy and D. J. Sheffield, eds., No Tapping Around Philology: A Festschrift in celebration and honor of Wheeler McIntosh Thackston Jr.'s 70th Birthday, Wiesbaden, 2014. 
R. Kinra, "Fresh Words for a Fresh World: Tāza Gū'i and the Poetics of Newness in Early Modern Indo-Persian Poetry," Sikh Formations 3.2 (2007), pp. 125-49.

-_-, "Secretary-Poets in Mughal India and the Ethos of Persian: The Case of Chandar Bhan Brahman", unpub. Ph.D. diss., University of Chicago, 2008.

-_- "Make It Fresh: Time, Tradition, and Indo-Persian Literary Modernity," in A. Murphy, ed., Time, History and the Religious Imaginary in South Asia, London, 2011a.

-_-, "This Noble Science: Indo-Persian Comparative Philology, ca. 1000-1800 CE," in Y. Bronner, W. Cox, and L. McCrea, eds., South Asian Texts in History: Critical Engagements with Sheldon Pollock, Ann Arbor, 2011b.

W. Kirmani, Dreams Forgotten: An Anthology of Indo-Persian Poetry, Aligarh, 1986.

R. Koselleck, Futures Past: On the Semantics of Historical Time, tr. Keith Tribe, New York, 2004.

C. Lefèvre, "The Court of 'Abd-ur-Rahim Kh hān-i Khāāān as a Bridge between Iranian and Indian Cultural Traditions", in T. de Bruijn and A. Busch, eds., Culture and Circulation in Early Modern India, Leiden, 2014.

S. Liechti, "Books, Book Endowments, and Communities of Knowledge in the Bukharan Khanate", unpub. Ph.D. diss., New York University, 2008.

P. E. Losensky, Welcoming Fighāni: Imitation and Poetic Individuality in the Safavid-Mughal Ghazal, Costa Mesa, CA, 1998.

A. Marashi, Nationalizing Iran: Culture, Power, and the State, 1870-1940, Seattle, 2008.

J. Marek, "Persian Literature in India," in J. Rypka, ed., History of Iranian Literature, Dordrecht, 1968.

R. Mathee, Persia in Crisis: Safavid Decline and the Fall of Isfahan, London, 2012.

J. Matini, “Āzar Bīgdelī,” in EIr, 2011; online: http://www.iranicaonline.org/articles/azar-bigdelihajj-lotf-ali-big (accessed 21 February 2016).

Abu al-Barakāt Monir Lahowri, Kārnāma, ed. S. M. Akram, Islamabad, 1977.

G. Morrison, J. Baldick, and M. R. Shafici Kadkani, History of Persian Literature from the Beginning of the Islamic Period to the Present Day, ed. G. Morrison, Leiden, 1981.

Ānand Rām Mokhles, Mer'āt al-estelāh, ed. Ch. Shekhar, H. R. Ghelichkani, and H. Yousefdahi, Delhi, 2013.

C. M. Naim, preface to Zikr-e Mir, New Delhi, 1999.

S. Naqvi, Farhangnevisi-ye färsi dar Hend va Pākestān, Tehran, 1962.

S. Pellò, "Safina-ye Košgu," EIr, 2008; online: http://www.iranicaonline.org/articles/safina-ye-kosgu (accessed 21 February 2016).

D. Perkins, Is Literary History Possible?, Baltimore, 1992.

J. R. Perry, "The Waning of Indo-Persian Lexicography: Examples from Some Rare Books and Manuscripts of the Subcontinent," in K. Eslami, ed., Iran and Iranian Studies: Essays in Honor of Iraj Afshar, Princeton, 1998.

S. Pollock, The Language of the Gods in the World of Men: Sanskrit, Culture, and Power in Premodern India, Berkeley, 2006.

M. Rahimpoor, "Seyari dar ahvāl-o āsāâr-e Serāj al-Din 'Ali Khān Ārzu-ye Akbarābādi," Āyena-ye Mirās n.s. 6.1 (Spring 2008/1387), pp. 289-318.

-—-, Bar kh ān-e ārzu, Qom, 2012.

N. Rashid, "Irān mem Ārzū shenāsi," Safina 10 (2012), pp. 206-19. 
K. L. Schwartz, "Bâzgasht-e Adabî (Literary Return) and Persianate Literary Culture in Eighteenth and Nineteenth Century Iran, India, and Afghanistan," unpub. Ph.D. diss., University of California, Berkeley, 2014.

M. R. Shafici Kadkani, Shā'eri dar hojum-e montaqedān: naqd-e adabi dar sabk-e Hendi pirāmun-e hazin lāhiji, Tehran, 1996.

S. Sharma, "The Land of Darkness: Images of India in the Works of Some Safavid Poets," Studies on Persianate Societies 1 (2003), pp. 97-110.

M. C. Smith, Literary Courage: Language, Land and the Nation in the Works of Malik al-Shu'arā Bahār, unpub. Ph.D. diss., Harvard University, 2006.

-_-, "Literary Connections: Bahār's Sabkshenāsi and the Bāzgasht-e Adabi," JPS 2.2 (2009), pp. 194209.

M. E. Subtelny, "A Taste for the Intricate: The Persian Poetry of the Late Timurid Period," ZDMG 136 (1986), pp. 56-79.

M. Tavakoli-Targhi, Refashioning Iran: Orientalism, Occidentalism and Historiography, New York, 2001.

E. Yarshater, "The Indian or Safavid Style: Progress or Decline?," in E. Yarshater, Persian Literature, New York, 1988.

I. R. Zaidi, "Vatan parast Khān-e Ārzū ki eslāhin,” in S. Mahli, ed., Serāj al-Din 'Ali Khān Ārzu: ek motāla'a, New Delhi, 2004. 